\title{
Immunologiske mekanismer for drap av kreftceller
}

\author{
For å få fullt utbytte av immunterapi må vi forstå hvordan immunsyste- \\ met utfører drap på kreftceller og hva som hindrer denne effekten.
}

Immunresponser mot kreft er komplekse prosesser, med involvering av flere celletyper og molekylære signalsystemer. Kreftceller angripes konstant av immunceller, men har egenskaper som kan dempe disse angrepene. For å kunne utnytte immunsystemets evne til å drepe kreftceller maksimalt er det viktig å forstå dette samspillet.

I en musemodell av benmargskreft har vi gjort studier av hvordan immunsystemet tar livet av kreften ved hjelp av T-lymfocytter og makrofager. Makrofager er sentrale celler i betennelsesreaksjoner og i kreftsvulster og kan utføre flere funksjoner. Når de stimuleres riktig, kan de drepe kreftceller slik de også dreper bakterier og andre mikrober. Men med feil stimuli kan makrofager legge til rette for vekst og spredning av kreftsvulsten.
I våre studier har vi vist hvordan makrofager bare kan virke over svært korte avstander og hvordan gjenværende kreftceller etter hvert endrer seg og vokser ut som resistente celler som ikke lar seg gjenkjenne av immunsystemet. Vi har også påvist hvordan man med medikamenter kan påvirke både mengden av makrofager og hvordan de oppfører seg, med potensielt stor betydning for kreftforløpet.

Våre resultater viser at det er stort potensial for makrofager i kreftbehandlingen, men vi har også påvist konkrete begrensninger. For å kunne utnytte disse immuncellene maksimalt må vi finne metoder som overvinner disse begrensningene.

Fredrik Hellem Schjesvold

fredrikschjesvold@gmail.com

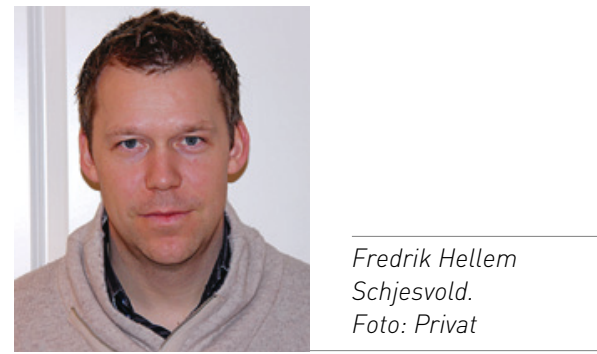

Disputas

Fredrik Hellem Schjesvold disputerte for ph.d.-graden ved Universitetet i Oslo 8.9.2016. Tittelen på avhandlingen er CD4+ T cell-induced macrophage cytotoxicity against tumor cells.

\section{Magnetisk resonanstomografi og kirurgisk behandling}

Introduksjonen av magnetisk resonanstomografi har påvirket spinalkirurgien på forskjellige måter.

Magnetisk resonanstomografi (MR) er vanligste bildeundersøkelse for å fremstille spinale sykdommer. Bruken har økt mye siden introduksjonen i Norge i 1986. Målet med forskningen vår var å evaluere ulike effekter som introduksjonen av denne undersøkelsen kan ha hatt på kirurgisk behandling av spinale sykdommer.

I den første av totalt tre studier har vi først beskrevet insidensraten av primære spinale svulster i perioden 1993-2011. Antall operasjoner for spinale svulster har økt betydelig i studieperioden - uavhengig av pasientalder eller histopatologisk type. I samme tidsrom har antall MR-tomografer her i landet økt fra åtte i 1993 til 125 i 2011. Økningen i kirurgisk behandling av spinale svulster synes å sammenfalle med økt tilgang til MR-diagnostikk.

I den andre studien undersøkte vi sammenhengen mellom grad av lumbal stenose vurdert ut fra MR-bilder og kliniske symptomer. MRbilder av pasienter som ble operert for lumbal stenose ble analysert og stenosegrad ble fastsatt (mild, moderat, alvorlig eller ekstrem stenose). Vi fant ingen korrelasjon mellom grad av stenose på MR-bildene og pasientens symptomer før operasjonen eller ett år senere.

I den siste studien ble pasienter som var blitt operert for lumbalt prolaps undersøkt med postoperativ MR. En restmasse i det opererte område i spinalkanalen som forsvinner etter tre måneder er et vanlig MRfunn hos dem som er symptomfri etter operasjonen. Dette vanskeliggjør tolkningen av postoperativ MR hos pasienter som har persisterende plager etter prolapskirurgi.

Resultatene gir økt kunnskap om MRundersøkelse og spinalkirurgi.

\section{Clemens Weber}

clemens.weber@gmail.com

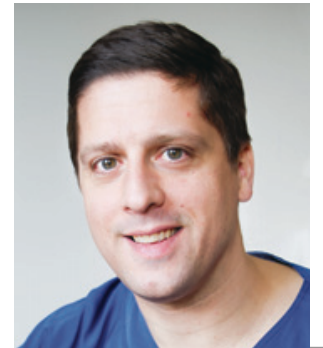

Clemens Weber. Foto: Svein Lunde, Stavanger universitetssjukehus

\section{Disputas}

Clemens Weber disputerte for ph.d.-graden ved Norges teknisk-naturvitenskapelige universitet 10.6.2016. Tittelen på avhandlingen er Magnetic resonance imaging in surgical spine care - diagnostic, predictive and epidemiological aspects. 